\title{
PENINGKATAN PENALARAN PENYELESAIAN SOAL HIGHER ORDER THINKING DALAM PEMBELAJARAN MATEMATIKA SMP MELALUI MODEL ECGV
}

\author{
Enung Sumarni1), Theresia Widyantini ${ }^{2}$ \\ ${ }^{1)}$ PPPPTK Matematika, Jl Kaliurang km 6 Sambisari, Yogyakarta; enungsumarni2@gmail.com \\ 2) PPPPTK Matematika, Jl Kaliurang km6 Sambisari, Yogyakarta;widterban@yahoo.com
}

\begin{abstract}
Abstrak. Penelitian dilakukan dengan tujuan untuk: 1) mengidentifikasi keadaan pembelajaran dalam kelas menggunakan model pembelajaran ECGV; 2) mengidentifikasi perbandingan peningkatan kemampuan berpikir tingkat tinggi dengan dan tanpa model pembelajaran ECGV; 3) mengkaji upaya meningkatkan faktor-faktor keterampilan berpikir tingkat tinggi siswa. Penelitian ini menggunakan pendekatan kuantitatif dengan paradigma rasionalistik. Dalam penelitian ini, pertama-tama diuraikan keadaan pembelajaran kelas kontrol, dimana siswa belajar seperti biasa, dan kelas eskperimen yang dilaksanakan dengan model ECGV (Eksplorasi, Konjekture, Generalisasi, Verifikasi). Kelas kontrol maupun ekperimen dilakukan perlakuan yang berbeda sehingga didapatkan perbedaan nilai gain ternormalisasi untuk mengindikasikan peningkatan ketercapaian dari tahap pembelajaran. Hasil penelitian ini menunjukkan bahwa: 1) Model ECGV merupakan model pembelajaran yang efektif untuk meningkatkan keterampilan dalam proses pembelajaran dan keterampilan berpikir siswa; 2) Tahapan ECGV harus dilakukan dengan selaras dari tahap 1 sampai 4 dengan memperhatikan faktor-faktor apa saja yang harus mejadi fokus untuk dilakukan perbaikan; 3) Hasil pembelajaran dalam kemampuan berpikir siswa yang terjadi pada kelas rendah lebih besar peningkatannya dibandingkan kelas tinggi; 4) Terdapat faktor yang menentukan dalam peningkatan nalar berpikir siswa; iklim kelas (lingkungan, guru dan sekolah), psikologi siswa, dan intelektual siswa.
\end{abstract}

Kata Kunci: Penalaran, HOTS, Model ECGV.

\section{REASONING SKILL IMPROVEMENT IN SOLVING THE HIGHER ORDER THINKING PROBLEMS IN MATHEMATICS TEACHING AND LEARNING FOR JUNIOR SECONDARY SCHOOL USING ECGV MODEL}

\begin{abstract}
The aim of this research is: 1) identifying the condition of teaching and learning in the classroom applying ECGV learning model; 2) comparing the improvement of higher order thinking skill when ECGV learning model is applied and without the ECGV learning model; 3) examining the efforts to improve the influencing factors of students' higher order thinking skills. This study applies quantitative approach with a rationalistic paradigm. At first, this study described the condition of the controlling class, in which students were learning as usual, as well as experimental class carried out applying the ECGV model (Exploration, Conjecture, Generalization, and Verification). Different treatments were applied to the controlling and experimental classes to have the difference in normalized gain values to indicate an improvement of
\end{abstract}


the achievement in this learning stage. The research results indicates that: 1) ECGV model is an effective learning model to improve skills within the learning process as well as students' thinking skills; 2) The ECGV stages should be applied from stages 1 to 4 accordingly, considering some factors that should be the focus for improvement; 3) Learning result indicated by in students' thinking abilities in the lower class increases greater than the higher class; 4) Some determining factors in the improvement of students' reasoning skills are found; class climate (environment, teacher and school), student psychology, and student intellectuals.

Keywords: Reasoning, HOTS, ECGV Model.

\section{Pendahuluan}

\subsection{Latar Belakang}

Bloom dengan jenjang taksonominya dalam buku pegangan pembelajaran berorientasi pada keterampilan tingkat tinggi (Ariyana, dkk, 2018), dituliskan bahwa keterampilan dibagi menjadi dua bagian yang penting dalam pembelajaran, yaitu: 1) keterampilan tingkat rendah yaitu kemampuan mengingat, memahami dan menerapkan atau disebut kemampuan LOTS , dan 2) kemampuan yang digolongkan ke dalam keterampilan berpikir tingkat tinggi atau HOTS yaitu berupa keterampilan menganalisis, mengevaluasi dan mencipta. Kemampuan kognitif berupa kata benda pada taksonomi Bloom selanjutnya dilakukan perubahan kemampuan kognitif kata kerja pada taksonomi Anderson. Proses tersebut membuat kemampuan kognitif tingkat tinggi diperoleh siswa menjadi sangat penting, karena di dalam proseslah stimulus melalui masalah kontekstual akan dapat diketengahkan memuat kata kerja operasionalnya.

Berbagai studi baik nasional maupun internasional menunjukkan bahwa kemampuan berpikir HOTS peserta didik di Indonesia masih rendah dan tertinggal jauh dengan negara-negara lain. Hal ini mendorong pemerintah Indonesia mengeluarkan berbagai kebijakan di bidang pendidikan yang diharapkan dapat meningkatkan kemampuan berpikir siswa pada level yang lebih tinggi, termasuk dalam pembelajaran matematika. Pembelajaran matematika yang memproses HOTS di dalamnya, akan berupaya siswa memiliki kemampuan menganalisis, mengevaluasi serta mencipta di dalam menyelesaikan soal-soal matematika yang diberikan. Proses tersebut dilakukan dengan harapan kemampuan HOTS akan tumbuh serta diaplikasikan dalam hidup dan kehidupannya sebagai pembelajar. Selain itu diharapkan dapat memperbaiki kinerja siswa, sebagai bekal mereka menjadi pembelajar yang problem solver, pembelajar yang mampu memecahkan masalah dengan kemandirian yang mereka miliki.

Salah satu permasalahan yang terjadi dalam pembelajaran matematika adalah kesulitan siswa dalam mengembangkan penalaran pada saat menyelesaikan soal-soal HOT. Hal ini tentu harus dicarikan solusinya mengingat bahwa kemampuan penalaran merupakan salah satu kunci keberhasilan siswa dalam menyelesaikan soal-soal HOT. Guru harus mampu memilih model-model pembelajaran yang tepat yang mampu mendorong pengembangan penalaran siswa. Salah satu model pembelajaran yang berpotensi dapat meningkatkan kemampuan penalaran siswa dalam menyelesaikan soal-soal HOT adalah model pembelajaran ECGV. Model pembelajaran ECGV, yang meliputi kegiatan eksplorasi, konjektur, generalisasi, dan verifikasi, memungkinkan siswa dapat mengembangkan penalarannya. Untuk itu dilakukan penelitian mengenai "Peningkatan kemampuan penalaran siswa menyelesaikan soal-soal matematika bertipe HOT pada siswa SMP di Indonesia melalui model ECGV". 


\subsection{Tujuan dan Pertanyaan Penelitian}

Penelitian ini dilakukan dengan tujuan untuk; 1) mengidentifikasi keadaan pembelajaran dalam kelas menggunakan model pembelajaran ECGV; 2) mengidentifikasi perbandingan peningkatan kemampuan berpikir tingkat tinggi dengan dan tanpa model pembelajaran ECGV; 3) mengkaji upaya meningkatkan faktor-faktor keterampilan berpikir tingkat tinggi siswa. Sedangkan pertanyaan penelitian ini adalah: 1) Bagaimana keadaan pembelajaran dalam kelas menggunakan model pembelajaran ECGV?; 2) Bagaimana perbandingan peningkatan kemampuan berpikir tingkat tinggi siswa yang belajar dengan dan tanpa model pembelajaran ECGV?; 3) Bagaimana upaya meningkatkan faktor-faktor keterampilan berpikir tingkat tinggi siswa?

Tujuan dan pertanyaan penelitian tersebut dirancang berdasarkan kesesuaian faktor-faktor peningkatan keterampilan berpikir tingkat tinggi siswa sebagai standar ideal dari hal-hal yang akan diteliti. Penelitian mengenai kondisi pembelajaran dalam kelas serta perubahan yang terjadi melalui model ECGV dilakukan untuk kemudian dibandingkan dengan tiap faktor yang menjadi acuan penelitian. Adapun faktor-faktor atau indikator peningkatan kemampuan berpikir siswa didapatkan dari literatur-literatur mengenai hal tersebut disesuaikan dengan kategori yang dibutuhkan dalam penelitian ini, sebagai berikut.

a. Lingkungan/kondisi kelas (classroom environment): iklim kelas (atmosper fisik dan psikologi); metode pengajaran dan pembelajaran; dan skap guru

b. Karakter psikologi (psychological characteristic): sikap terhadap pembelajaran; motivasi pencapaian; dan kontrol lokus internal diri

c. Karakteristik intelektual (intellectual characteristic): kadar kecerdasan dan kemampuan nalar

\section{Metodologi Penelitian}

\subsection{Pendekatan Penelitian}

Penelitian ini menggunakan pendekatan kuantitatif dengan paradigma rasionalistik. Pendekatan kuantitatif dalam penelitian ini menggunakan analisis gain ternormalisasi, serta dilengkapi rasionalisasi dari pendekatan kualitatif untuk mengidentifikasi faktor dalam setiap tahap model ECGV. Nilai yang didapatkan dari gain ternormalisasi menjadi indikator kemampuan siswa untuk selanjutnya dianalisis ketercapaiannya dengan indikator pembelajaran siswa. Paradigma rasionalistik merupakan paradigma yang diambil dari dasar rasionalisme yang melihat manusia lahir dengan membawa potensi (innate knowledge) yang memosisikan anak menjadi subjek dari pendidikan (Siddiq dkk, 2018: 43), sehingga dalam penelitian ini objek penelitian dilihat dalam konteksnya dengan tahapan sebagai berikut:

a. Kerangka teori sebagai persiapan penelitian: konsepsualisasi teoritik (sebagai grand teori atau grand concept) diperlukan.

b. Kedudukan objek dengan lingkungannya: objek dilihat dalam konteksnya (konstruksi teoritik yang lebih mencakup).

c. Generalisasi hasil, dua tahap: 1). Generalisasi dari objek spesifik atas hasil uji-maknaempirik, dan 2). Pemaknaan hasil uji reflekstif kerangka konseptualisasi teoritik (grand theory) dengan pemaknaan indikasi empirik.

Melalui paradigma rasionalistik, penelitian ini menggunakan konsep teori keterampilan berpikir tingkat tinggi pada pendidikan. Konsep tersebut menjadi kerangka dasar penelitian yang selanjutnya diturunkan kedalam indikator-indikator penelitian. Indikator keterampilan 
berpikir tingkat tinggi dalam pendidikan menjadi patokan analisis untuk dilanjutkan pada generalisasi hasil. Hasil penelitian didapatkan dari nilai gain ternormalisasi yang diasumsikan menjadi gambaran umum dari kondisi di lapangan. Asumsi tersebut diasosiasikan kembali dengan indikator keterampilan siswa sehingga didapatkan pemaknaan kualitatif dari generalisasi yang dilakukan.

Adapun perhitungan gain ternormalisasi digunakan sebagai analisis tingkat hasil belajar siswa dalam metode keterampilan berpikir tingkat tinggi. Elemen yang dapat dianalisis dari perhitungan gain adalah efektivitas model pembelajaran terhadap peningkatan konsep, kemampuan mengaitkan informasi baru dengan informasi yang telah dimiliki sebelumnya, dan kemampuan menyimpan informasi ke memori jangka panjang, serta keterlibatan aktif dalam melakukan pembelajaran.

\subsection{Unit Penelitian}

Unit amatan dalam penelitian ini yaitu guru (pengajar) dan siswa. di 3 kota, yaitu Kota Yogyakarta, Kota Surabaya, dan Kota Bandung, terdiri dari 198 siswa pada kelas eksperimen dan 196 siswa pada kelas kontrol. Di Kota Yogyakarta, penelitian dilaksanakan di SMP Negeri 5 Yogyakarta (kelas tinggi) dan SMP Muhammadiyah 1 Yogyakarta. DI SMP Negeri 5 Yogyakarta responden terdiri dari 32 siswa kelas eksperimen (VIII-I) dan 32 siswa kelas kontrol (VIII-J). Di SMP Muhammadiyah 1 (kelas rendah) responden terdiri dari 27 siswa kelas eksperimen (VIII-D) dan 30 siswa kelas kontrol (VIII-c). Kedua penelitian dilakukan di Kota Surabaya penelitian dilaksanakan di SMP Negeri 1 (kelas tinggi) dan SMP Negeri 13 (kelas rendah). Di SMP Negeri 1 responden terdiri dari 37 siswa kelas eksperimen (VIII-H) dan 32 siswa kelas kontrol (VIII-I). Sedangkan di SMP Negeri 13 responden terdiri dari 39 siswa kelas eksperimen (VIII-C) dan 38 siswa kelas kontrol (VIII-F). Terakhir di Kota Bandung, penelitian dilaksanakan di SMP Negeri 14 (kelas tinggi) dan SMP Negeri 48 (kelas rendah). Di SMP Negeri 14 responden terdiri 32 siswa kelas eksperimen (VIII-B) dan 32 siswa kelas kontrol (VIII-H). Selanjutnya di SMP Negeri 48 (kelas rendah) responden terdiri dari 32 siswa kelas eksperimen (VIII-H) dan 32 siswa kelas kontrol (VIII-A).

Seperti yang dijelaskan pada pendekatan penelitian, metode kuantitatif dilakukan menggunakan perhitungan indeks gain. Indeks gain ditunjukkan dengan tingkat peningkatan siswa pada kelas eksperimen maupun kontrol. Adapun Rumus N-gain (g) yang dilakukan dalam peneltian ini menurut Hake (1999) adalah sebagai berikut;

$$
N \text {-gain }(g) \quad \frac{(\text { nilai pos tes }- \text { nilai pre tes })}{\text { (nilai maks ideal }- \text { nilai pre tes })}
$$

- $\mathrm{g} \geq 0,7 \quad$ : indeks gain tinggi

- $0,3 \leq \mathrm{g}<0,7 \quad$ : Indeks gain sedang

- $\mathrm{g}<0,3 \quad:$ Indeks gain rendah

\section{Hasil Penelitian}

\subsection{Identifikasi Keadaan Pembelajaran dalam Kelas}

Model ECGV merupakan model pembalajaran dengan tahapan yang lebih jelas dan terarah untuk meningkatkan kemampuan penalaran siswa. Model ECGV dirasakan tepat untuk meningkatkan keterampilan berpikir dengan diawali analisis keadaan siswa untuk kemudian dilakukan rekayasa yang sesuai dengan kondisi di lapangan. Berikut ini pelaksanaan model ECGV yang dilaksanakan di ketiga kota tempat penelitian. 
Tahap Eksplorasi

Tabel 1. Tahap eksplorasi keadaan dalam kelas

\begin{tabular}{|c|c|}
\hline Model I & Peserta Kelas Ek \\
\hline $\begin{array}{l}\text { 1. Kemampuan menemukan kemiripan/ } \\
\text { kesamaan masalah pada setiap masalah } \\
\text { yang diberikan }\end{array}$ & $\begin{array}{l}\text { 1. Memerlukan waktu yang lama, } \mathrm{n} \\
\text { memerlukan 'trigger' atau bantuan } \\
\text { guru }\end{array}$ \\
\hline
\end{tabular}

$\rightarrow 5 / 10$ ketercapaian: realitas di lapangan, siswa masih memerlukan bantuan dari guru untuk waktu yang cukup lama dalam memahami masalah yang diberikan. Setelah itu siswa dapat menemukan solusi dari permasalahan yang diberikan. Karena alasan waktu dan bantuan diawal, ketercapaian tahap ini diasumsikan memiliki keberhasilan 50\%.

2. Kemampuan menemukan apa yang belum 2 2. Memerlukan waktu yang lama, masih diketahui, apa yang sudah diketahui, serta apa hubungannya dengan menggunakan operasi hitung dari setiap masalah yang diberikan

$\rightarrow$ 5/10 ketercapaian: serupa dengan tahap 1, di tahap 2 ini juga siswa masih memmerlukan waktu yang cukup lama dan bantuan pengajar, sehingga diasumsikan memiliki keberhasilan $50 \%$.

3. Membuat hubungan menggunakan operasi 3 3emerlukan waktu yang lama, masih hitung pada setiap kondisi 1 dan kondisi 2 dari masalah yang diberikan memerlukan 'trigger' atau bantuan dari guru

7/10 ketercapaian: Pada tahap ini, siswa hanya dituntut untuk membiat hubungan. Karena itu walaupun masih memerlukan waktu yang lama dan bantuan, namun keberhasilannya diasumsikan mencapai $70 \%$.

4. Menemukan kesimpulan tentang 4 4. Sebagian besar kelompok siswa dapat kemiripan apa yang diperoleh dari ketiga masalah yang diberikan yaitu: ada dua hal yang belum diketahui atau harus dicari dan ada dua hubungan yang diketahui menemukan hal ini, karena pada tahap sebelumnya sudah terbiasa untuk menemukan kemiripan dari masalah yang diberikan.

$\rightarrow$ 10/10 ketercapaian: tahap terakhir pada model eksplorasi ini diasumsikan keberhasilannya mencapai $100 \%$ karena siswa telah beradaptasi dengan tiga tahap sebelumnya dan mampu memecahkan masalah yang dihadapi.

Dari 4 tahap model eksplorasi, disimpulkan keberhasilan siswa mengikuti pembelajaran di kelas eksperimen untuk menyelesaikan tahapan eksplorasi mencapai angka 6.75 dari 10 atau $67.5 \%$. Angka persentase ketercapaian tiap tahapan tersebut didapatkan dari analisis rasionalisasi untuk mengkuantifikasikan perbandingan antara tahap eksplorasi sebagai tahapan ideal dengan realisasi dalam kelas. Dengan kata lain, keterampilan berpikir siswa untuk menemukan persamaan, perbedaan, memahami masalah, dan menemukan hubungan mencapai efektifitas 50\% namun masih dapat ditingkatkan dengan tahap-tahap selanjutnya.

Tabel 2. Tahap konjekture keadaan dalam kelas

\section{Tahap Konjekture}

\begin{tabular}{|c|c|}
\hline Model ECGV & Peserta Kelas Eksperimen \\
\hline 1. Menyatakan kembali kedua hubungan yang & 1. a). Masih memerlukan bantuan guru \\
\hline
\end{tabular}




\begin{tabular}{|c|c|}
\hline Model ECGV & Peserta Kelas Eksperimen \\
\hline $\begin{array}{l}\text { sudah ditemukan pada tahap } 1 \text { dengan } \\
\text { menggunakan pemisalan } \\
\text { Contoh pada masalah } 1 \text {, Pecahan } 1 \\
\text { dimisalkan A, dan pecahan kedua } \\
\text { dimisalkan B. }\end{array}$ & $\begin{array}{l}\text { sebagai fasilitator untuk membantu } \\
\text { siswa membuat pemisalan. } \\
\text { b). Sebanyak } 50 \% \text { siswa dapat membuat } \\
\text { pemisalan seperti yang dipandu dalam } \\
\text { LK. }\end{array}$ \\
\hline \multicolumn{2}{|c|}{$\begin{array}{l}\rightarrow 7 / 10 \text { ketercapaian: pada tahap ini, untuk mebuat permisalan siswa masih memerlukan } \\
\text { bantuan guru, sebanyak } 50 \% \text { siswa dapat melakukannya. Oleh karena itu diasumsikan } \\
\text { keberhasilannya mencapai } 60-70 \% \text {. }\end{array}$} \\
\hline $\begin{array}{l}\text { 2. Menyatakan kembali dengan menggunakan } \\
\text { penjumlahan saja. (pengurangan } \\
\text { dinyatakan dengan penjumlahan dengan } \\
\text { lawan bilangan) }\end{array}$ & $\begin{array}{l}\text { 2. Siswa diingatkan kembali tentang operasi } \\
\text { pengurangan adalah operasi penjumlahan } \\
\text { dengan lawan bilangan pengurangnya. Hal } \\
\text { ini mempermudah siswa untuk } \\
\text { menyelesaikan tahapan ini. }\end{array}$ \\
\hline
\end{tabular}

$\rightarrow$ 10/10 ketercapaian: siswa dengan mudah menyelesaikan tahap ini walaupun dengan panduan awal terlebih dahulu, sehingga diasumsikan tahap 2 mencapai keberhasilan $100 \%$.

3. Kemampuan menuliskan hasil 3 3. Sebagian besar kelompok siswa bisa membayangkan bahwa orang pertama memiliki kemampuan 'menghilangkan' memiliki kedua bilangan tersebut, orang dengan operasi tambah yang mereka kedua memiliki kedua bilangan tetapi salah satunya negatif, apa yang terjadi jika kedua orang tersebut menggabungkan apa yang dimilikinya? Adakah yang saling menghilangkan? lakukan di dalam penyelesaian soal.

10/10 ketercapaian: siswa dapat dengan mudah melalui tahapan ini, maka diasumsikan keberhasilannya $100 \%$

4. Kemampuan melihat dari hasil gabungan 4 . Kemampuan hal ini masih harus diarahkan tersebut, apakah menemukan nilai yang guru. Hanya $30 \%$ siswa di kelas masih ada (tidak hilang)? eksperimen yang percaya diri langsung menyelesaikannya.

$\rightarrow$ 3/10 ketercapaian: siswa masih mmbutuhkan pengarahan sehingga hanya $30 \%$ yang mampu memecahkan masalah pada tahap ini.

5. Kemampuan membuat dugaan bagaimana 5 . Sebagian besar siswa mampu mendapatkan nilai komponen lainnya menyelesaikannya, karena merupakan (pecahan lainnya) dengan cara kemampuan mengulang dari yang sudah "mengurangi" yaitu hubungan yang satu diproses sebelumnya.

"dikurangi" hubungan yang lain

$\rightarrow 10 / 10$ ketercapaian: seperti yang dijelaskan bahwa siswa mampu mengulang proses yang telah dilalui sebelumnya sehingga keberhasilan pada tahap ini mencapai $100 \%$.

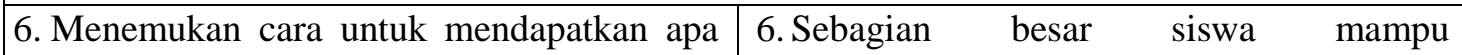
yang dicari, yaitu dengan menjumlah atau menyelesaikan hal ini. mengurangi kedua hubungan yang diperoleh 


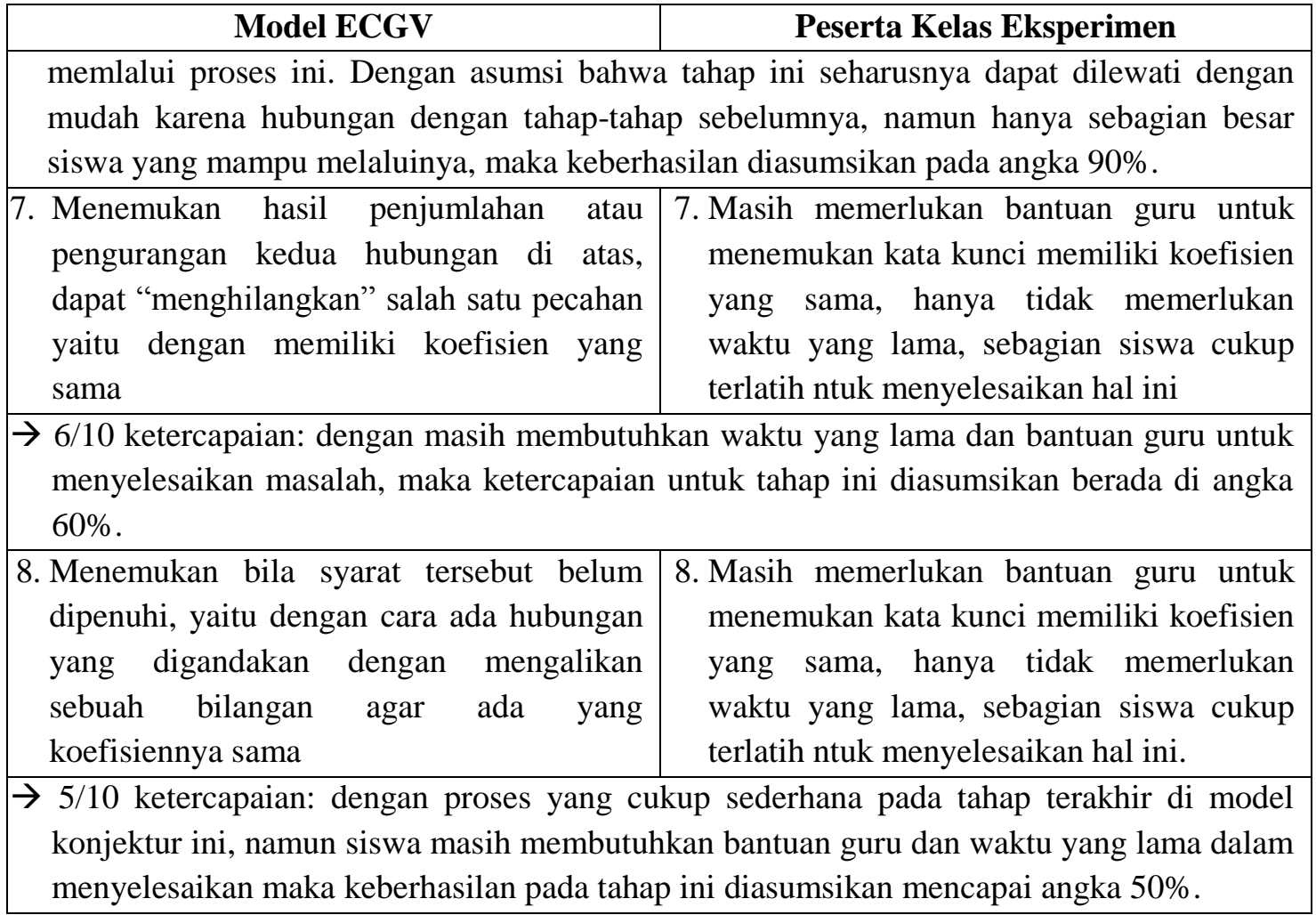

Dari 8 tahap model konjekture, disimpulkan keberhasilan siswa mencapai angka 7.5 dari 10 atau $75 \%$. Keterampilan berpikir siswa mulai meningkat dengan diawali tahap eksplorasi sebelumnya, hingga pada tahap konjekture siswa relatif lebih mudah menemukan pemecahan masalah. Siswa dapat menghubungkan variabel dan menemukan cara yang lebih rumit pada metode ini dengan asumsi peningkatan keterampilan siswa mencapai angka keberhasilan $75 \%$.

Tabel 3. Tahap generalisasi keadaan dalam kelas

\section{Tahap Generalisasi}

\begin{tabular}{|c|c|}
\hline Model ECGV & Peserta Kelas Eksperimen \\
\hline $\begin{array}{l}\text { 1. Semua hal SPLDV dengan metode } \\
\text { eliminasi, disampaikan kepada siswa, dan } \\
\text { guru memastikan siswa memahami istilah- } \\
\text { istilah formal yang akan digunakan } \\
\text { selanjutnya }\end{array}$ & $\begin{array}{l}\text { 1. Semua siswa menyimak penjelasan guru, } \\
\text { dipastikan siswa memahami melalui } \\
\text { brainstorming yang dilakukan oleh guru }\end{array}$ \\
\hline \multicolumn{2}{|c|}{$\begin{array}{l}\rightarrow \text { 10/10 ketercapaian: tahap ini memiliki ketercapaian } 100 \% \text {, siswa diasumsikan sudah } \\
\text { beradaptasi sehingga mampu dengan cepat menyelesaikan proses pemecahan masalah }\end{array}$} \\
\hline $\begin{array}{l}\text { 2. Menyelesaikan masalah bersifat matematis } \\
\text { sesuai urutan -urutan pada dua tahapan } \\
\text { sebelumnya }\end{array}$ & $\begin{array}{l}\text { 2. Semua siswa pada setiap kelompok bisa } \\
\text { mengerjakan hal ini }\end{array}$ \\
\hline \multicolumn{2}{|c|}{$\begin{array}{l}\text { 10/10 ketercapaian: seluruh siswa kembali mampu memecahkan dengan mudah maka } \\
\text { keberhasilan diasumsikan mencapai } 100 \%\end{array}$} \\
\hline $\begin{array}{l}\text { 3. Mengeliminasi variabel } \mathrm{x} \text { yang diketahui } \\
\text { dari kedua kondisi pada masalah yang }\end{array}$ & $\begin{array}{l}\text { 3. Semua siswa pada setiap kelompok bisa } \\
\text { mengerjakan hal ini }\end{array}$ \\
\hline
\end{tabular}




\begin{tabular}{|l|l|}
\hline \multicolumn{1}{|c|}{ Model ECGV } & Peserta Kelas Eksperimen \\
\hline diberikan & \\
\hline $\begin{array}{l}10 / 10 \text { ketercapaian: seluruh siswa kembali mampu memecahkan dengan mudah maka } \\
\text { keberhasilan diasumsikan mencapai 100\% }\end{array}$ \\
\hline $\begin{array}{l}\text { 4. Mengeliminasi vaiabel y yang diketahui } \\
\text { dari kedua kondisi pada masalah yang } \\
\text { diberikan }\end{array}$ & $\begin{array}{l}\text { 4. Semua siswa pada setiap kelompok bisa } \\
\text { mengerjakan hal ini }\end{array}$ \\
\hline $\begin{array}{l}10 / 10 \text { ketercapaian: tahap terakhir pada model generalisasi ini diasumsikan } \\
\text { keberhasilannya mencapai 100\% karena siswa telah beradaptasi dengan tiga tahap } \\
\text { sebelumnya dan mampu memecahkan masalah yang dihadapi. }\end{array}$ \\
\hline
\end{tabular}

Dari 4 tahap model generalisasi, disimpulkan keberhasilan siswa mencapai angka 10 dari 10 atau $100 \%$. Dengan kata lain, keterampilan berpikir siswa untuk memecahkan masalah telah meningkat dbandingkan kedua model sebelumnya. Pada tahap generalisasi siswa dapat menghubungkan kembali dan menemukan pola dari tahap-tahap yang sebelumnya telah dilalui.

Tabel 4. Tahap generalisasi keadaan dalam kelas

\section{Tahap Verifikasi}

\begin{tabular}{|c|c|}
\hline Model ECGV & \multicolumn{2}{|c|}{ Peserta Kelas Eksperimen } \\
\hline 1. Kemampuan melakukan pemeriksaan & 1. Sebagian besar siswa cukup lancar \\
kebenaran metode eliminasi, dengan cara & menyelesaikan pada tahapan ini, mereka \\
mengecek kebenaran solusi pada beberapa & secara kolaboratif menyelesaikan soal- \\
sistem persamaan linear dua variabel yang & soal yang ada pada LK dengan \\
diperoleh dengan metode eliminasi & kemampuan yang sudah mereka miliki \\
& pada dua tahap sebelumnya \\
\hline
\end{tabular}

$\rightarrow$ 10/10 ketercapaian: seluruh siswa kembali mampu memecahkan dengan lancar dan bekerjasama dalam menyelesaikannya, maka keberhasilan diasumsikan mencapai $100 \%$

2. Kemampuan menyelesaikan permasalahan 2 2. Sebagian besar siswa cukup lancar SPLDV yang diberikan, dengan menggunakan metode eliminasi, kemudian menunjukkan bahwa penyelesaian yang diperoleh adalah benar dengan menguji pada semua persamaan dalam sistem menyelesaikan pada tahapan ini, mereka secara kolaboratif menyelesaikan soalsoal yang ada pada LK dengan kemampuan yang sudah mereka miliki pada dua tahap sebelumnya

$\rightarrow$ 10/10 ketercapaian: seluruh siswa kembali mampu memecahkan dengan lancar dan bekerjasama dalam menyelesaikannya, maka keberhasilan diasumsikan mencapai $100 \%$

Dengan dua tahap yang dilakukan pada tahapan verifikasi, keberhasilan mencapai $100 \%$. Dengan demikian dapat disimpulkan memiliki keberhasilan $100 \%$ berdasarkan analisis rasionalistik dari kuantifikasi realisasi tahapan verifikasi yang dilakukan.

\subsection{Perbandingan Peningkatan Kemampuan Berpikir Tingkat Tinggi Melalui Model ECGV}

Perbandingan peningkatan kemampuan berpikir tingkat tinggi siswa dilakukan dengan menghitung indeks gain dari kelas eksperimen dan kelas kontrol ditiap sekolah yang menjadi unit penelitian. Perhitungan indek gain dilakukan dengan analisis rasional bahwa terdapat perbedaan pencapaian dari diberlakukannya model ECGV dalam pembelajaran di kelas 
eksperimen dengan pencapaian model pembelajaran di kelas kontrol yang memiliki latar belakang kondisi siswa yang berbeda pula.

Penelitian di Kota Yogyakarta dilakukan di SMP Negeri 5 sebagai kriteria sekolah favorit, dan SMP Muhammadiyah 1 sebagai kriteria sekolah biasa. Di SMP Negeri 5, kelas eksperimen terdiri dari 32 siswa dan juga 32 siswa pada kelas kontrol. Di Kelas rendah, terdapat 27 siswa kelas eksperimen dan 30 siswa pada kelas kontrol. Dari penelitian yang dilakukan, didapatkan hasil perbandingan indeks gain seperti terlihat pada Gambar 1.

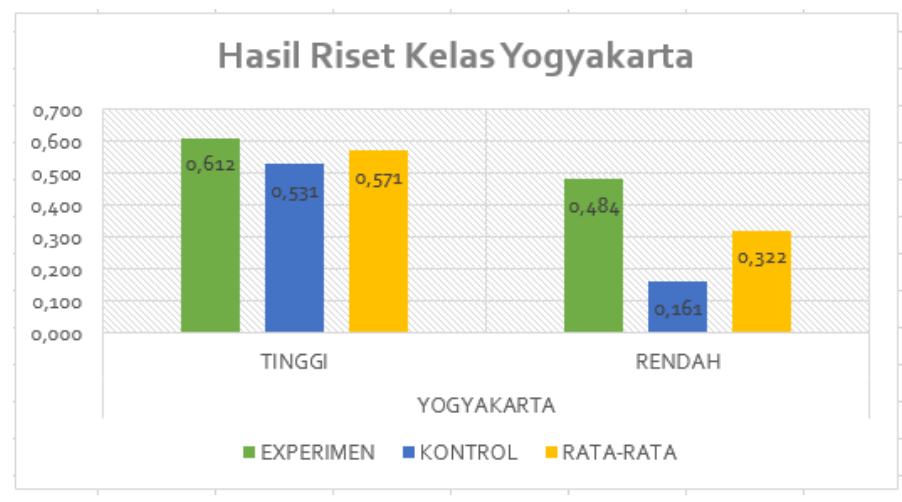

Gambar 1. Hasil riset penigkatan kemampuan berpikir di Kelas Yogyakarta

Pada kelas tinggi, tingkat peningkatan pembelajaran masuk dalam kategori indeks gain sedang yaitu 0,571 (warna kuning pada grafik kelas tinggi, Indeks gain sedang $=0,3 \leq \mathrm{g}<$ 0,7). Rata-rata indeks gain menunjukan adanya peningkatan yang cukup atau sedang dari hasil eksperimen yang dilakukan di kelas tinggi, baik pada kelas kontrol maupun kelas eksperimen. Adapun pada kelas rendah, peningkatan pembelajaran berada pada indeks sedang yaitu 0,32 (warna kuning pad agrafik kelas rendah). Apabila dicermati lebih lanjut, terdapat perbedaan yang cukup signifikan antara peningkatan pada kelas eksperimen dan kelas kontrol. Kelas eksperimen memiliki peningkatan yang cukup besar yaitu 0,48 (warna hijau pada grafik kelas rendah) dibandingkan pada kelas kontrol dengan peningkatan yang rendah, yaitu 0,16 (warna biru pada grafik kelas rendah). Hal ini menunjukan bahwa pada kelas rendah, perlakuan atau rekayasa harus dilakukan untuk meningkatkan tingkat pembelajaran pada siswa.

Analog dengan penelitian di Kota Jogjakarta, penelitian di Kota Surabaya dilakukan di SMP Negeri 1 sebagai kriteria sekolah favorit, dan SMP Negeri 13 sebagai kriteria sekolah biasa. Di SMP Negei 1, kelas eksperimen terdiri dari 37 siswa dan juga 32 siswa pada kelas kontrol. Di Kelas rendah, terdapat 39 siswa kelas eksperimen dan 38 siswa pada kelas kontrol. Dari penelitian yang dilakukan, didapatkan hasil yang disajikan pada Gambar 2. 


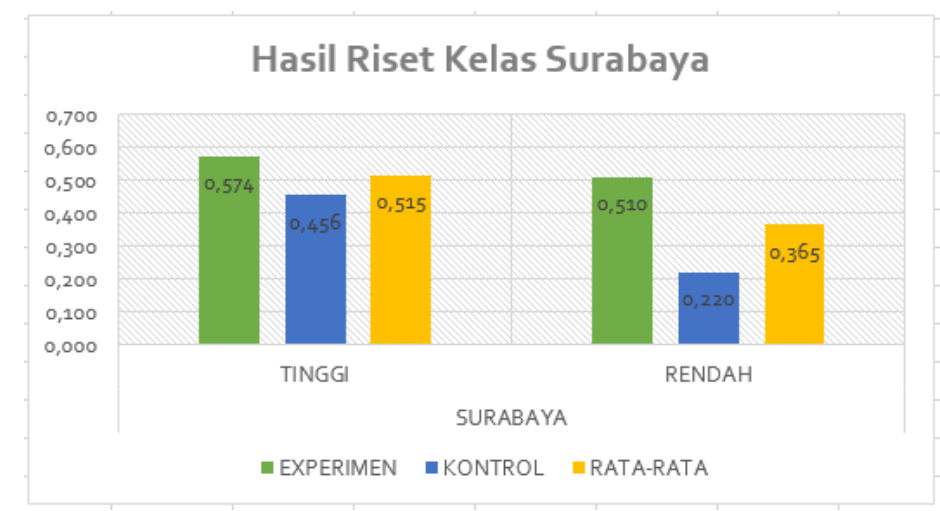

Gambar 2. Hasil riset penigkatan kemampuan berpikir di Kelas Surabaya

Serupa dengan hasil penelitian di Kota Yogyakarta, peningkatan pembelajaran pada kelas rendah memiliki perbedaan yang lebih signifikan antara kelas kontrol dan eksperimen dibandingkan dengan kelas tinggi. Pada kelas tinggi, rata-rata peningkatan di angka sedang, yaitu 0,515 dengan perbedaan antara kelas ekperimen dan kelas kontrol hanya 0,12. Sedangkan pada kelas rendah perbedaannya mencapai hampir angka $0,3(0,29)$ dengan ratarata peningkatan pembelajaran di kategori sedang, yaitu 0,365.

Analog dengan penelitian di Kota Jogjakarta dan Surabaya, penelitian di Kota Bandung dilakukan di SMP Negeri 14 sebagai kriteria sekolah favorit, dan SMP Negeri 48 sebagai kriteria sekolah biasa. Di SMP Negei 14, kelas eksperimen terdiri dari 32 siswa dan juga 32 siswa pada kelas kontrol. Di Kelas rendah, terdapat 31 siswa kelas eksperimen dan 32 siswa pada kelas kontrol. Dari penelitian didapatkan hasil yang tersaji pada Gambar 3.

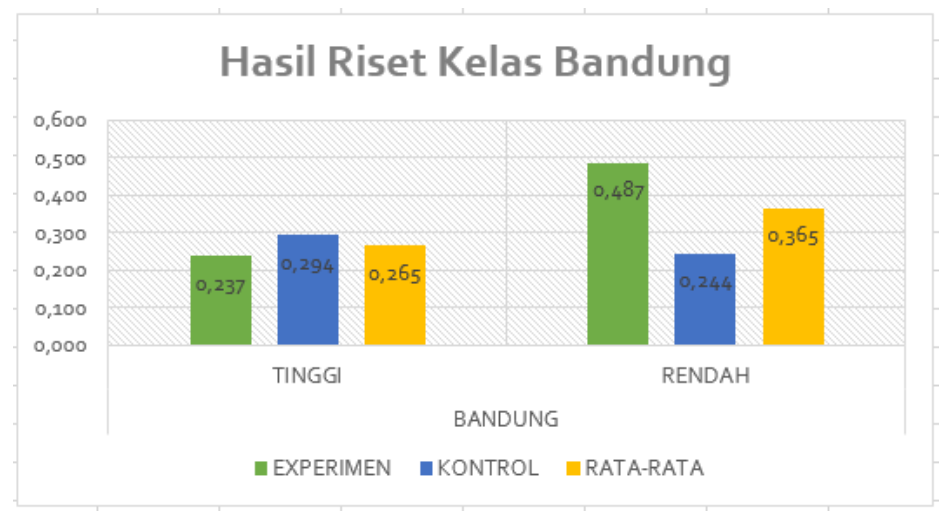

Gambar 3. Hasil riset penigkatan kemampuan berpikir di Kelas Bandung

Berbeda dengan hasil dari kedua kota yang telah dibahas sebelumnya, di Kota Bandung, rata-rata peningkatan pembelajaran pada kelas rendah memiliki angka yang lebih tinggi dibandingkan pada kelas tinggi. Pada kelas tinggi, rata-rata peningkatan berada pada indeks rendah dengan angka 0,26. Dan peningkatan pada kelas kontrol justru menunjukkan angka yang lebih tinggi dibandingkan kelas eksperimen walaupun perbedaannya tidak signifikan. Hal ini menjadi anomali dari asumsi sebelumnya bahwa pada kelas tinggi memiliki peningkatan yang relatif lebih tinggi pula dibandingkan di kelas rendah. Begitu pula perbandingan antara kelas kontrol yang diasumsikan memiliki peningkatan yang lebih rendah dibandingkan kelas eksperimen. Adapun pada kelas rendah, indeks gain masuk dalam kategori sedang yaitu 0,36 dengan perbedaan antara kelas kontrol dan ekperimen cukup signifikan di angka 0,24 . 
Dari penelitian di Kota Surabaya dan Kota Jogjakarta pada kelas tinggi, didapatkan indeks gain yang relatif lebih tinggi dibandingkan pada kelas rendah. Hal ini tidak terjadi pada penelitian yang dilakukan di kelas Kota Bandung, Penyebabnya dapat dianalisis dengan menyesuaikan faktor-faktor yang mempengaruhi latar belakang siswa dan guru dalam berjalannya pembelajaran yang akan dibahas pada sub-bab pembahasan selanjutnya. Namun dengan rekapitulasi rata-rata indeks gain pada ketiga kota yang dilakukan penelitiannya, didapatkan hasil sebagai berikut;

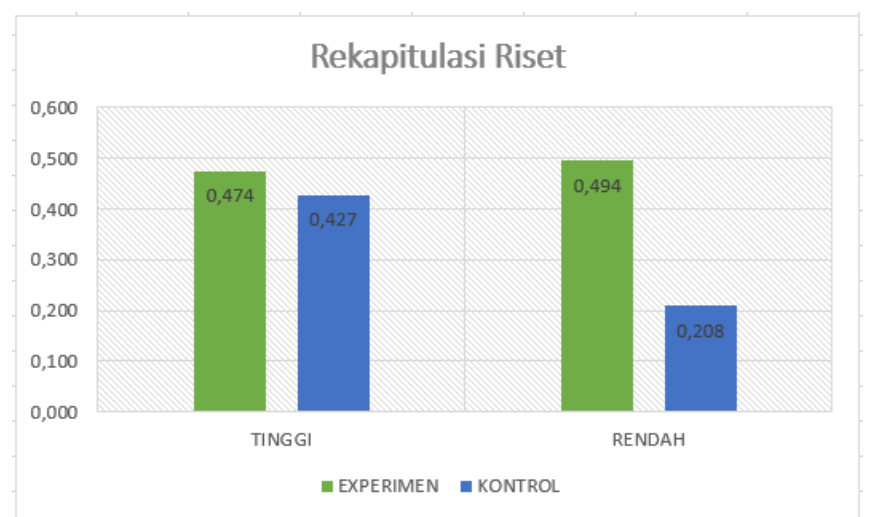

Gambar 4. Rekapitulasi hasil riset peningkatan pembelajaran dalam kelas

Hasil peningkatan penalaran siswa pada kelas eksperimen kelas tinggi tidak begitu signifikan hasilnya, terlihat dari sebelum treatment dan setelah treatment, nilai peningkatan hasil penalaran siswa tidak jauh berbeda walaupun ada sedikit peningkatan sebesar 0,047 (kelas tinggi) Treatment yang dilakukan di kelas eksperimen pada kelas rendah memiliki pengaruh yang cukup besar dibandingkan pada kelas tinggi. Hasil peningkatan penalaran siswa di kelas rendah sangat terlihat, yaitu terdapat selisih indeks gain sebesar 0,29 (perbedaan grafik warna hijau dan biru pada kelas rendah) dengan implementasi model ECGV (Ekplorasi Conjecture - Generalisasi - Verifikasi) pada kelas eksperimen.

\subsection{Kesesuaian Faktor-faktor untuk Meningkatkan Keterampilan Berpikir Tingkat Tinggi Siswa dengan Keadaan Pembelajaran dalam Kelas}

Dari tiap kelas pada tiap kota, hasil penelitian pada kelas eksperimen menunjukan ketercapaian hasil dari tiap prosesnya sebagai berikut;

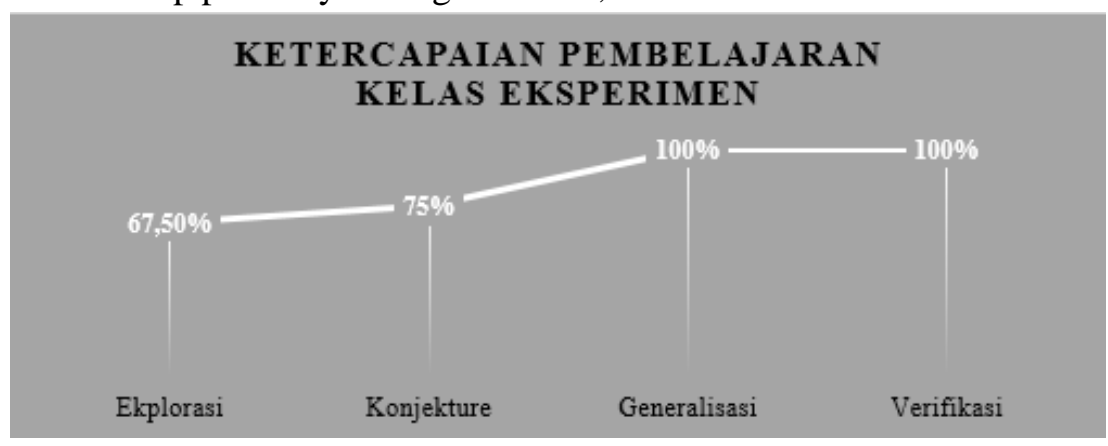

Gambar 5. Ketercapaian pembelajaran peningkatan kemampuan berpikir tingkat tinggi melalui pelaksanaan model ECGV kelas eksperimen

Dari 4 tahap yang dilakukan, terlihat pencapaian pembelajaran dari tahap eksplorasi ke tahap verifikasi mengalami peningkatan. Hal ini menunjukan bahwa tahap ECGV merupakan model pembelajaran yang efektif untuk meningkatkan keterampilan dalam proses 
pembelajaran dan keterampilan berpikir siswa. Setelah mengetahui faktor-faktor yang menjadi indikator dari peningkatan kemampuan siswa berpikir tingkat tinggi dalam matematika, maka penyesuaian rekayasa yang harus dilakukan pada tiap faktornya menjadi penting. Urgensi untuk meningkatkan faktor-faktor dari HOTS ini mempertimbangkan hasil penelitian nilai gain dengan model ECGV yang telah dilakukan. Sehingga diharapkan aspekaspek terkait yang perlu ditingkatkan dapat menjadi prioritas utama untuk diberlakukan dalam pembelajaran matematika siswa SMP. Berikut ini faktor-faktor yang perlu ditingkatkan fokus pelaksanaannya sesuai dengan model ECGV.

Tabel 5. Penyesuaian Faktor yang Perlu Ditingkatkan dalam Peningkatan HOTS

\begin{tabular}{|c|c|c|c|c|c|}
\hline \multirow{2}{*}{ Klasifikasi } & \multirow{2}{*}{ Faktor } & \multicolumn{4}{|c|}{ Tahap } \\
\hline & & Eksplorasi & Konjekture & Generalisasi & Verifikasi \\
\hline \multirow{3}{*}{$\begin{array}{l}\text { Lingkungan/ } \\
\text { Kondisi Kelas } \\
\text { (Classroom } \\
\text { Environment) }\end{array}$} & Iklim kelas & $\mathrm{V}$ & $\mathrm{V}$ & $\mathrm{V}$ & $\mathrm{V}$ \\
\hline & $\begin{array}{l}\text { Metode } \\
\text { pengajaran dan } \\
\text { pembelajaran }\end{array}$ & V & V & V & $\mathrm{V}$ \\
\hline & Sikap guru & V & V & V & V \\
\hline \multirow{3}{*}{$\begin{array}{l}\text { Karakter } \\
\text { Psikologi } \\
\text { (Psychological } \\
\text { Characteristic) }\end{array}$} & $\begin{array}{l}\text { Sikap terhadap } \\
\text { pembelajaran }\end{array}$ & V & V & V & V \\
\hline & $\begin{array}{l}\text { Motivasi } \\
\text { pencapaian }\end{array}$ & $\mathrm{V}$ & & & \\
\hline & $\begin{array}{l}\text { Kontrol lokus } \\
\text { internal diri }\end{array}$ & $\mathrm{V}$ & & & \\
\hline \multirow{2}{*}{$\begin{array}{l}\text { Karakteristik } \\
\text { Intelektual } \\
\text { (Intellectual } \\
\text { Characteristic) }\end{array}$} & $\begin{array}{l}\text { Kadar } \\
\text { kecerdasan }\end{array}$ & & $\mathrm{V}$ & V & V \\
\hline & $\begin{array}{l}\text { Kemampuan } \\
\text { nalar }\end{array}$ & & V & V & $\mathrm{V}$ \\
\hline
\end{tabular}

Mulai dari proses eksplorasi hingga verifikasi, tentunya perlu dilakukan perbaikan pada tiap faktornya sehingga mendapatkan hasil peningkatan pembelajaran yang lebih maksimal. Namun pada tabel 4 diperlihatkan yang menjadi fokus utama atau hal yang perlu ditingkatkan dari tiap prosesnya ditandai dengan tanda V. Pada 4 faktor pertama, yaitu iklim kelas, metode pengajaran-pembelajaran, sikap guru, dan sikap siswa terhadap pembelajaran memiliki urgensi utama untuk menjadikan proses pembelajaran sesuai dengan tiap latar belakang siswa. Keempat faktor ini menjadi kunci utama dari tahap awal pembelajaran sehingga perbaikannya perlu ditingkatkan pada proses ekplorasi hingga verifikasi.

Aspek psikologi baik pada siswa maupun guru, yaitu motivasi pencapaian dan kontrol lokus internal dapat ditekankan perbaikannya pada tahap eksplorasi sehingga semua pihak memiliki kerangka berpikir yang sama terlebih dahulu. Apabila kerangka motivasi dan fokus dalam diri memiliki arah yang sama pada tahap eksplorasi, maka ketiga tahap setelahnya dapat dengan mudah dilalui. Sehingga faktor mengenai intelektual, yaitu kadar kecerdasan dan kemampuan nalar, dapat difokuskan pada tahap konjekture, generalisasi, dan verifikasi. Dengan demikian, faktor intelektual siswa dapat berkembang secara bertahap sesuai dengan tujuan penelitian untuk meningkatkan kemampuan berpikir tingkat tinggi pada pembelajaran matematika SMP. 


\section{Kesimpulan dan Saran}

\subsection{Kesimpulan}

Berdasarkan hasil penelitian ini didapatkan kesimpulan sebagai berikut:

1. Model ECGV merupakan model pembelajaran yang efektif untuk meningkatkan keterampilan dalam proses pembelajaran dan keterampilan berpikir siswa. Hal ini terlihat pada pencapaian pembelajaran dari tahap eksplorasi ke tahap verifikasi mengalami peningkatan

2. Tahapan ECGV harus dilakukan dengan selaras dari tahap 1 sampai 4 dengan memperhatikan faktor-faktor apa saja yang harus mejadi fokus untuk dilakukan perbaikan. Tingkat ketercapaian pembelajaran untuk peningkatan keterampilan berpikir siswa, meningkat selaras dengan tahap model ECGV yang dilakukan (terutama di kelas rendah). Hal tersebut didasarkan pada analisis bahwa dua tahapan awal model ECGV, yaitu tahap eksplorasi dan konjekture, adalah dua tahapan awal yang memerlukan kerja siswa dengan bantuan guru sebagai trigger. Namun pada dua tahap terakhir (generalisasi dan verifikasi) siswa dapat mengikuti tahapan pembelajaran dengan ketercapaian peningkatan berpikir yang meningkat.

3. Hasil pembelajaran dalam kemampuan berpikir siswa yang terjadi pada kelas rendah lebih besar peningkatannya dibandingkan kelas tinggi. Hal tersebut terlihat dari selisih indeks gain antara kelas kontrol dan kelas eksperimen yang lebih besar pada kelas rendah dibandingkan selisihnya di kelas tinggi.

4. Terdapat faktor yang menentukan dalam peningkatan nalar berpikir siswa; iklim kelas (lingkungan, guru dan sekolah), psikologi siswa, dan intelektual siswa. Faktor-faktor yang mempengaruhi adanya peningkatan keterampilan berpikir merupakan indikator penting yang menjadikan rekayasa perbaikan atau perlakuan tenaga pendidik lebih terfokus dan terspesifikasi. Aspek lingkungan, psikologi dan intelektual internal harus menjadi fokus utama sehingga keberjalanan pembelajaran meningkat selaras, baik dari faktor eksternal maupun internal siswa dan guru.

\subsection{Saran}

Perlu dilakukan penelitian lebih lanjuta agar didapatkannya variabel yang lebih detail dari setiap faktor dengan diberlakukannya model pembelajar ECGV pada setiap kelas dalam pembelajaran matematika. Penelitian lebih lanjut juga diperlukan mengenai identifikasi faktor-faktor untuk meningkatkan kemampuan penalaran sehingga didapatkan hasil penelitian dengan tingkat generalitas yang lebih tinggi. Untuk meningkatkan kemampuan penalaran siswa, perencana perlu menetapkan kalangan yang menjadi sasaran pengembang sehingga dapat memberikan pembekalan yang cukup waktu dan cukup konten. Faktor penetapan tempat penelitian juga tetap merupakan faktor utama sehingga penelitian ke lapangan akan lebih mudah dilaksanakan, sehingga harus memperhatikan faktor ini beserta sarana dan prasarana pendukung yang tersedia. 


\section{Daftar Pustaka}

Ahmad, N.S., Mochd, S.A. \& Abdul, H.A. 2017. Inculcalating Higher-Order Thinking Skills in Mathematics: Why Is It So Hard?. Man In India, 97 (13), 51-62.

Boon, T.T. 2013. Meta-Cognition \& Values. Penang Malaysia: SEAMEO RECSAM.

Chow, F. 2013. Assessment for Learning. Penang Malaysia: SEAMEO RECSAM.

Chow, F. 2013. Structur Problem Solving. Penang Malaysia: SEAMEO RECSAM.

Daniel, A.P. 2010. On Computer-Based Assessment of Mathematics. University of Nottingham: Thesis for Degree of Doctor of Philosophy.

Hake.R. 1999. Analyzing Change/Gain Score. Indiana: Indiana University.

House, P.A. 1995. Connecting Mathematics across the Curriculum Yearbook. Virginia: The National Council of Teachers of Mathematics, Inc.

Koay, S.S. (2013). Mathematics Education Trends in the 21th Century. Penang Malaysia: SEAMEO RECSAM.

Mee, L.S. 2013. Observation Skills. Penang Malaysia: SEAMEO RECSAM.

NCTM. 2000. Curriculum and Evaluation Standard for School Mathematics. Virginia: The National Council of Teachers of Mathematics, Inc.

Panduan Kurikulum Tingkat Satuan Pendidikan. 2006. Jakarta: Departemen Pendidikan Nasional.

Panduan Pelatihan 'Overseas Training. 2013. Penang Malaysia: SEAMEO RECSAM.

Prayoonsri, Budsankom. Tatsirin Sawangboon, dkk. 2015. Factors Affecting Higher Order Thinking Skills of Students: a Meta-Analytic structural Equation Modeling Study. Educational Research and Reviews. 10(19), 2639-2652

Preechaporn, W. 2013. 21th Secondary Mathematics:Enhancing Higher Order Thinking Skills and Integrated Values Education. Penang Malaysia: SEAMEO RECSAM.

Sumarni, E. 2006. Pembelajaran Matematika Pendekatan Gabungan Langsung dan Tidak Langsung untuk Meningkatkan Daya Matematika Siswa. Tesis pada PPS UPI Bandung: tidak dipublikasikan.

Tanujaya, B. 2016. Development of an Instrument to Measure Higher Order Thinking Skills in Senior High School Mathematics Instruction. Journal of Education and Practice, 7(21), 144-148 Diakses dari http://www..mathshell.com/papers.php, pada 23 November 2018.

Van Dijk, E. 2014. Influences on Performance in Higher Order Thinking Skills. Utrecht University: Research in Mathematics Education.

\footnotetext{
How to Cite:

Sumarni, E., Widyantini, T.(2019). Peningkatan penalaran penyelesaian soal higher order thinking dalam pembelajaran matematika SMP melalui model ECGV. IDEAL MATHEDU: Indonesian Digital Journal of Mathematics and Education, 6(1), 569-582.
} 